Arc. Com. Health • Desember 2021

p-ISSN 2302-139X e-ISSN 2527-3620

Vol. 8 No. 514 - 522

\title{
PENGETAHUAN MENGENAI GARAM BERIODIUM PADA IBU RUMAH TANGGA DI WILAYAH KERJA PUSKESMAS TAMPAKSIRING I
}

\author{
Kadek Nuansa Putri Wulandari, Ni Ketut Sutiari* \\ Program Studi Sarjana Kesehatan Masyarakat Fakultas Kedokteran Universitas Udayana \\ Jalan PB. Sudirman Denpasar, Bali 80232
}

\begin{abstract}
ABSTRAK
Universal Salt Iozation merupakan strategi untuk mengurangi defisiensi iodium dengan menambahkan iodium kedalam garam. Dalam evaluasi kinerja gizi tahun 2020 Bali termasuk dalam Provinsi yang masih rendah pada konsumsi garam beriodium yaitu sebesar $80,6 \%$ dari target $82 \%$. Cakupan penggunaan garam beriodium akan dipengaruhi oleh tingkat pengetahuan masyarakat mengenai garam beriodium. Tujuan penelitian ini untuk mengetahui pengetahuan Ibu Rumah Tangga mengenai garam beriodium di wilayah kerja Puskesmas Tampaksiring I. Jenis penelitian ini adalah deskriptif kuantitatif dengan pendekatan cross-sectional. Populasi penelitian yaitu ibu rumah tangga yang berada di wilayah kerja Puskesmas Tampaksiring I dengan sampel sebanyak 111. Pengambilan sampel dilakukan dengan accidental sampling. Teknik pengumpulan data menggunakan wawancara dan observasi. Instrumen penelitian menggunakan kuesioner dan checklist. Dilaksanakan pada April - Juni 2021 dan dianalisis menggunakan Analisis Univariat. Hasil penelitian ini memperoleh mayoritas tamat SMP (25,2\%) dan 75,7\% sebagai Ibu Rumah Tangga (IRT). Sebesar 55,9\% responden sudah menggunakan garam beriodium dan 59,5\% responden memiliki pengetahuan baik mengenai garam beriodium.
\end{abstract}

Kata Kunci: Pengetahuan, Garam Beriodium, Ibu Rumah Tangga

\section{ABSTRACT}

Universal Salt Iozation is a strategy to reduce iodine deficiency by adding iodine to salt. In the evaluation of nutritional performance in 2020, Bali is included in a province that is still low on iodized salt consumption, which is $80.6 \%$ of the $82 \%$ target. The level of public knowledge about iodized salt will influence the scope of use of iodized salt. The purpose of this study was to determine the knowledge of housewives regarding iodized salt in the work area of the Tampaksiring I Public Health Center. This type of research was quantitative descriptive with a cross-sectional approach. The research population is housewives who are in the working area of the Tampaksiring I Public Health Center with a sample of 111. Accidental sampling does sampling. Data collection techniques using interviews and observation. The research instrument used a questionnaire and a checklist. Conducted in April - June 2021 and analyzed using Univariate Analysis. The results of this study obtained that the majority graduated from junior high school $(25.2 \%)$ and $75.7 \%$ as housewives (IRT). $55.9 \%$ of respondents have used iodized salt and $59.5 \%$ of respondents have good knowledge of iodized salt.

Keywords: Knowledge, Iodized Salt, Housewife

\section{PENDAHULUAN}

Masalah gizi merupakan suatu permasalahan masyarakat yang disebabkan oleh multifaktor. Malnutrisi merupakan salah satu permasalahan universal yang terjadi pada semua lingkaran kehidupan tidak memandang usia, jenis kelamin, daerah tempat tinggal juga keadaan ekonomi. Gangguan Akibat Kurang Iodium (GAKI) merupakan salah satu permasalahan gizi yang akan berdampak pada kelangsungan hidup dan kualitas sumber daya manusia
(Wirakusuma, 2016). GAKI merupakan beberapa gejala yang muncul akibat tubuh kekurangan iodium dalam jangka waktu lama dan lebih banyak dialami oleh kelompok rawan seperti wanita usia subur (WUS), anak usia sekolah, balita dan ibu hamil (Merryana Adriani, 2012). GAKI berpengaruh erat terhadap gangguan perkembangan kecerdasan dan mental. Tahun 2009 pemerintah Indonesia menetapkan program penanggulangan GAKI yang bertumpu pada konsumsi garam beriodium oleh masyarakat yang 
dikenal sebagai Universal Salt Iozation (USI).

USI merupakan strategi yang disusulkan oleh WHO, UNICEF dan ICCIDD pada tahun 2007 untuk mengurangi defisiensi iodium ditingkat masyarakat dengan menambahkan iodium kedalam garam yang dijual kepada masyarakat (World Health Organization, 2007). Darmono 2009 menyatakan bahwa lebih dari $90 \%$ rumah tangga mengonsumsi garam beriodium yakni garam yang difortifikasi dengan 3080 part per million ( $\mathrm{ppm}$ ) iodium atau zat kalium iodat (KIO3) (Darmono, 2009).

Menurut Buku Saku Pemantauan Status Gizi tahun 2017 Bali menempati posisi kedua terendah yaitu 58\% rumah tangga mengonsumsi garam beriodium setelah Nusa Tenggara Barat yaitu 56,3\% (Kemenkes RI, 2017). Dalam evaluasi kinerja gizi tahun 2020 Bali termasuk dalam Provinsi yang masih rendah pada konsumsi garam beriodium yaitu sebesar 80,6\% dari target 82\% (Kemenkes RI, 2021). Kabupaten Gianyar termasuk dalam Kabupaten yang cakupan rumah tangga menggunakan garam beriodium sebesar $49,6 \%$ masih dibawah target $85 \%$. Pada tahun 2018 cakupan rumah tangga menggunakan garam beriodium pada bulan Agustus sebesar 74\%, tahun 2019 sebesar $78 \%$ dan pada tahun 2020 turun menjadi 71\% (Dinkes Gianyar, 2020a).

Salah satu UPT Puskesmas dengan persentase rumah tangga menggunakan garam beriodium rendah pada tahun 2017 di Kabupaten Gianyar yaitu Puskesmas Tampaksiring I sebesar 62,8\%, menurun pada tahun 2018 menjadi 48,7\% dari target 85\% dan pada tahun 2019 kembali menurun menjadi $44,9 \%$ dari target $85 \%$ (Dinkes Gianyar, 2020b). Puskesmas Tampaksiring I juga memiliki desa yang menjadi lokasi fokus (lokus) stunting di Kabupaten Gianyar yaitu desa Sanding dan Manukaya (Dinkes Gianyar, 2019). Pada tahun 2018 persentase TB/U balita di Puskesmas Tampaksiring I sebesar 23,1 \%, sudah berada dibawah target tahun 2020 sebesar 24,1\% (Kemenkes RI, 2020). Penggunaan garam beriodium pada rumah tangga akan berpengaruh terhadap status gizi anak (TB/U) karena iodium merupakan salah satu zat yang berperan dalam masa pertumbuhan anak. Faktor risiko stunting salah satunya diakibatkan karena konsumsi garam beriodium yang kurang (Imelda, 2018). Anak yang mengonsumsi garam dengan kandungan iodium kurang cenderung mengalami pertumbuhan linier yang tidak normal. Tinggi anak lebih pendek dibandingkan dengan anak yang mengkonsumsi garam cukup mengandung iodium (Devi, 2012a). Pengetahuan merupakan hasil yang diakibatkan dari mengetahui sesuatu dan terjadi setelah seseorang melakukan suatu penginderaan terhadap suatu objek melalui panca indra yaitu pendengaran, penglihatan, penciuman, perasaan dan perabaan (Notoatmodjo, 2003). Terdapat 6 tingkatan pengetahuan menurut Notoatmodjo yaitu tahu, memahami, mengaplikasikan, analisis, sintesis dan evaluasi. Tujuan penelitian ini yaitu untuk mengetahui pengetahuan Ibu rumah tangga mengenai garam beriodium di wilayah kerja Puskesmas Tampaksiring I.

\section{METODE PENELITIAN}


Desain penelitian yang digunakan dalam penelitian ini yaitu deskriptif dengan pendekatan cross sectional untuk mengetahui gambaran ketersediaan dan persepsi ibu rumah tangga mengenai garam beriodium. Penelitian ini dilakukan di wilayah kerja Puskesmas Tampaksiring I pada bulan Maret hingga Juni 2021. Populasi dalam penelitian ini yaitu seluruh ibu rumah tangga yang berada di wilayah kerja Puskesmas Tampaksiring I dan berdomisili di wilayah kerja Puskesmas Tampaksiring 1 sebanyak 6365 ibu rumah tangga. Sampel dari penelitian ini yaitu Ibu rumah tangga yang berada di wilayah kerja Puskesmas Tampaksiring

I yang memenuhi kriteria inklusi yaitu ibu rumah tangga yang berusia 2050 tahun, bersedia mengikuti penelitian dan kriteria ekslusi yaitu sedang sakit dan berada di luar daerah pada saat penelitian berlangsung. Jumlah sampel dalam penelitian ini yaitu 111 responden dengan menggunakan accidental sampling. Teknik pengumpulan data yang dilakukan dalam penelitian ini yaitu wawancara menggunakan kuesioner dan observasi yang dalam penyebarannya dibantu oleh kader posyandu pada beberapa banjar karena keterbatasan pada masa pandemic COVID-19. Teknik analisis data yang digunakan dalam penelitian deskriptif ini yaitu analisis univariate dengan nomor ethical clearance 1509/UN14.2.2.VII.14/LT/2021.

\section{HASIL}

Tabel 1. Karakteristik Responden

\begin{tabular}{lcc}
\hline Karakteristik & $\mathbf{f}$ & $\mathbf{\%}$ \\
\hline Usia (tahun) & 13 & 11,7 \\
$19-29$ & 88 & 79,3 \\
$30-49$ & 10 & 9 \\
$50-64$ & & \\
Pendidikan Terakhir & 26 & 23,4 \\
Tidak Sekolah & 25 & 22,5 \\
SD/Sederajat & 28 & 25,2 \\
SMP/Sederajat & 23 & 20,7 \\
SMA/Sederajat & 9 & 8,1 \\
PT/ Diploma & & \\
Pekerjaan & 1 & 0,9 \\
Tidak Bekerja & 6 & 5,4 \\
Petani & 3 & 2,7 \\
PNS/TNI/POLRI & 5 & 4,5 \\
Pegawai Swasta & 10 & 9 \\
Pedagang/Wiraswasta & 84 & 75,7 \\
Ibu Rumah Tangga (IRT) & &
\end{tabular}




\begin{tabular}{lll}
\hline Lainnya & 2 & 1,8 \\
\hline
\end{tabular}

Responden pada penelitian ini adalah 111 ibu rumah tangga yang tersebar di 3 Desa dan 8 banjar di wilayah kerja Puskesmas Tampaksiring I yaitu Desa Tampaksiring, Manukaya dan Sanding dengan 8 Banjar dari total 3 Desa yang ada di wilayah kerja Puskesmas I Tampaksiring. Masing- masing banjar tersebut antara lain Br. Bantas (10,8\%), Br. Malet (12,6\%), Br. Manik Tawang (13,5\%), Br. Penempahan (9\%), Br. Penendengan
$(13,5 \%)$, Br. Sanding Bitra $(13,5 \%)$, Br. Sareseda (13,5\%) dan Br. Tegal Suci (13,5\%). Usia responden paling banyak berada pada rentang 30-49 tahun (88\%).

$$
\text { Latar belakang pendidikan }
$$
responden mayoritas tamat SMP sebanyak $(25,2 \%)$ dan sebanyak $(8,1 \%)$ responden yang menyelesaikan PT/ Diploma. Sebagian besar responden $(75,7 \%)$ sebagai Ibu Rumah Tangga (IRT).

Tabel 2. Distribusi Kandungan Iodium pada garam yang digunakan oleh Ibu Rumah Tangga di Wilayah Kerja Puskesmas I Tampak Siring

\begin{tabular}{lcc}
\hline Variabel & $\begin{array}{c}\mathbf{f} \\
(\mathbf{n}=\mathbf{1 1 1})\end{array}$ & $\mathbf{\%}$ \\
\hline Kandungan Iodium Garam & & \\
Tidak Berwarna & 33 & 29,7 \\
$<30$ ppm (Ungu Pucat) & 16 & 14,4 \\
30-80 ppm (Ungu Tua) & 62 & 55,9 \\
\hline
\end{tabular}

Berdasarkan Tabel 5.2, didapatkan 55,9\% ibu rumah tangga sudah menggunakan garam beriodium dengan kandungan 3080 ppm dan terdapat $29,7 \%$ ibu rumah tangga belum menggunakan garam beriodium berdasarkan hasil uji dengan menggunakan iodine test.

Tabel 3. Tingkat Pengetahuan Ibu Rumah Tangga mengenai Garam Beriodium di Wilayah Kerja Puskesmas I Tampaksiring

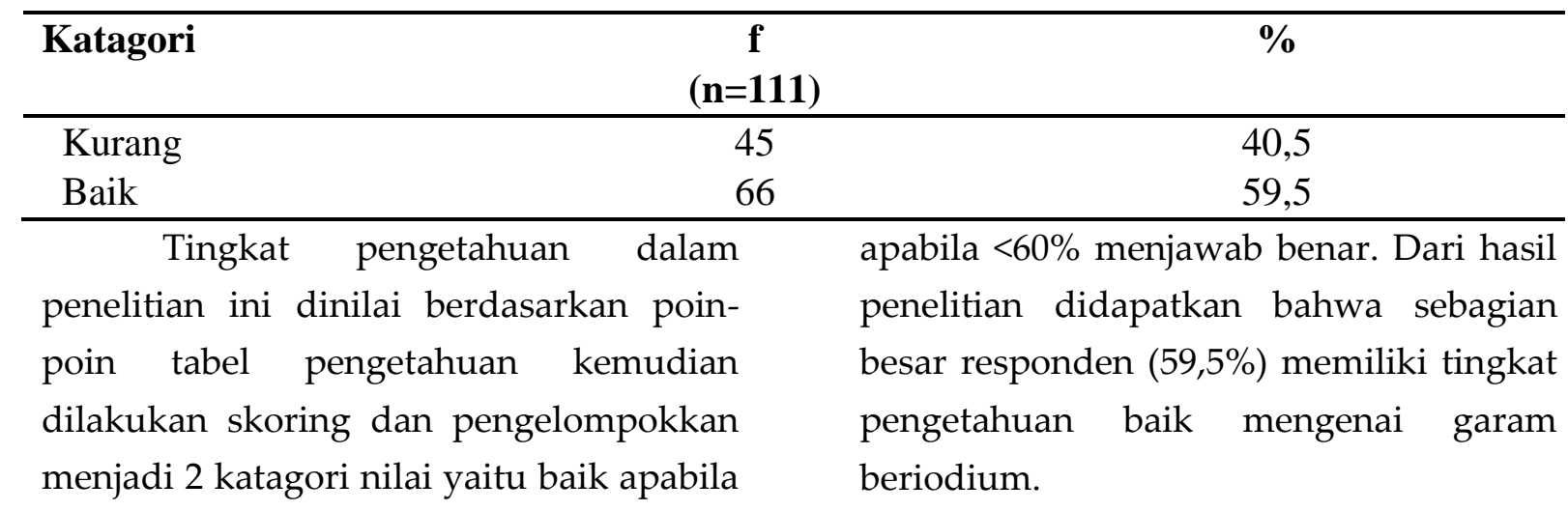
$>70 \%$ menjawab benar, dan kurang 
Tabel 4. Jawaban Pertanyaan Pengetahuan mengenai Garam Beriodium pada Ibu Rumah Tangga di Wilayah Kerja Puskesmas I Tampak Siring (n=111)

\begin{tabular}{|c|c|c|c|c|}
\hline \multirow{2}{*}{ Pernyataan } & \multicolumn{2}{|c|}{ Benar } & \multicolumn{2}{|c|}{ Salah } \\
\hline & $\mathbf{f}$ & $\%$ & $\mathbf{f}$ & $\%$ \\
\hline Definisi garam beriodium & 97 & 87,4 & 13 & 11,7 \\
\hline Menurut ibu apa manfaat garam & 99 & 89,2 & 12 & 10,8 \\
\hline \multicolumn{5}{|l|}{ beriodium? } \\
\hline Sumber Iodium & 103 & 92,8 & 8 & 7,2 \\
\hline Warna garam ketika iodine test & 32 & 28,8 & 79 & 71,2 \\
\hline Garam beriodium yang baik & 106 & 95,5 & 5 & 4,5 \\
\hline Cara penggunaan garam beriodium & 26 & 23,4 & 85 & 76,6 \\
\hline Teknik pemasakan yang dapat & 36 & 32,4 & 75 & 67,6 \\
\hline \multicolumn{5}{|l|}{ menghilangkan kadar iodium } \\
\hline Cara menyimpan garam beriodium & 96 & 86,5 & 15 & 13,5 \\
\hline yang benar & & & & \\
\hline Tujuan garam beriodium disimpan & 66 & 59,5 & 45 & 40,5 \\
\hline \multicolumn{5}{|l|}{ dalam wadah tertutup } \\
\hline Kandungan iodium yang di anjurkan & 91 & 82 & 20 & 18 \\
\hline oleh pemerintah & & & & \\
\hline
\end{tabular}

Berdasarkan Tabel 4 sebagian besar responden menjawab benar pada masing- masing item pertanyaan. Namun, pada item pertanyaan mengenai garam dengan kandungan iodium baik apabila di tetesi dengan iodine test akan berwarna, kapan ibu memasukan garam beriodium pada masakan dan teknik pemasakan yang dapat menghilangkan kadar iodium pada garam, pada 3 item pertanyaan tersebut sebagian responden menjawab salah.

\section{DISKUSI}

\section{Kandungan Iodium dalam Garam}

Sebelum dilakukan pengisian kuesioner mengenai pengetahuan terlebih dahulu ditanyakan screening question yaitu mengenai Ibu mengetahui tentang garam beriodium. Dari hasil kuesioner yang diterima sebesar 97,3\% ibu rumah tangga pernah mendengar tentang garam beriodium sedangkan 2,7\% responden belum pernah mendengar tentang garam beriodium. Pada item pertanyaan mengenai menggunakan atau tidaknya garam beriodium dirumah, sebesar $81,1 \%$ responden menjawab menggunakan dan sisanya tidak menggunakan. Hasil observasi dan iodium test menunjukkan sebanyak 70,3\% responden menggunakan garam beriodium yang ditandai oleh adanya warna ungu. Sedangkan 33 responden $(29,7 \%)$ tidak menggunakan garam beriodium dilihat dari hasil iodine test yang tidak berwarna. Dari 78 (70,3\%) responden sebanyak 62 sampel $(55,8 \%)$ 
berwarna ungu tua atau memiliki kandungan iodium sekitar 30-80 ppm dan $14,4 \%$ sampel berwarna ungu muda yaitu memiliki kandungan iodium dibawah 30 ppm.

Lebih dari setengah ibu rumah tangga di wilayah kerja Puskesmas Tampaksiring I sudah menggunakan garam beriodium berdasarkan hasil iodium test. Namun, masih ada ibu rumah tangga yang belum menggunakan garam beriodium. Berdasarkan hasil wawancara dengan ibu rumah tangga yang tidak menggunakan garam beriodium, beralasan bahwa sudah terbiasa menggunakan garam Bali yang dijual dipasar, Beliau sendiri belum mengetahui perbedaan antara garam beriodium dengan garam biasa sehingga lebih memilih membeli dan menggunakan garam biasa yang sudah terbiasa digunakan sehari-hari. Begitupula dengan hasil wawancara salah satu kader, alasan mengapa terdapat ibu rumah tangga yang belum menggunakan garam beriodium karena biasanya yang berbelanja kebutuhan sehari-hari adalah orang tua (sudah berusia tua) sehingga tidak mengetahui garam yang baik digunakan dirumah yang terpenting yaitu yang dibeli merupakan garam dan memberikan rasa asin pada makanan. Hasil penelitian diatas sejalan dengan pendapat Pavlov dalam Ade Hikmat (2014) dimana suatu perilaku manusia terbentuk melalui pembiasaan (Hikmat, 2014).

\section{Pengetahuan Ibu Rumah Tangga mengenai Garam Beriodium}

Pengetahuan dalam Notoatmodjo (2010) merupakan hasil dari tahu yang terjadi setelah seseorang melakukan penginderaan terhadap suatu objek yang terjadi melalui panca indera yaitu penglihatan, pendengaran, penciuman, rasa dan peraba (Notoatmodjo, 2010). Pengetahuan merupakan suatu pemahaman seseorang mengenai topik yang diberikan. Pengetahuan adalah kemampuan untuk menerima, mempertahankan dan menggunakan informasi yang dipengaruhi oleh pengalaman dan keterampilan. Sebagian besar pengetahuan seseorang berasal dari pendidikan baik pendidikan formal dan informal, pengalaman pribadi maupun orang lain, lingkungan dan media massa (Siltrakool, 2018).

Berdasarkan hasil penelitian pengetahuan ibu rumah tangga mengenai garam beriodium didapatkan sebagian besar Ibu memiliki kategori baik (59,5\%). Dilihat dari 10 item pertanyaan mengenai pengetahuan yang ditanyakan, terdapat 3 item pertanyaan yang lebih banyak dijawab salah oleh responden yaitu yang pertama mengenai garam dengan kandungan iodium baik apabila di tetesi dengan iodine test akan berwarna? Pada item pertanyaan ini hanya $28,8 \%$ responden menjawab benar. Sedikit responden yang mengetahui bahwa apabila garam yang ditetesi dengan iodium test berwarna ungu tua maka garam tersebut mengandung sekitar 30-80 ppm iodium. Hal ini menunjukkan bahwa responden belum mampu dalam mengidentifikasi garam dengan kandungan iodium yang baik.

Pertanyaan kedua yaitu kapan ibu memasukan garam beriodium pada masakan sebagian besar responden menjawab salah (76,6\%). Kurangnya 
pengetahuan responden mengenai garam beriodium menyebabkan tidak optimalnya penggunaan garam beriodium di rumah tangga. Hanya sebesar 23,4\% masyarakat yang mengetahui bahwa kandungan iodium pada garam dapat berkurang akibat cara penggunaan garam yang kurang tepat. Sebagian besar responden tidak mengetahui bahwa cara penggunaan garam yang benar yaitu pada saat masakan akan dihidangkan. Temuan ini sejalan dengan penelitian Wirakusuma (2016) dimana, cara penggunaan garam pada saat pemasakan sebagian besar masih tidak tepat $(87,8 \%)$ (Wirakusuma, 2016). Hal ini disebabkan karena responden beranggapan apabila menambahkan garam setelah pemasakan, rasa masakan tidak akan menyerap. Selain itu menurut Martha (2015) menambahkan garam ketika memasak sudah menjadi kebiasaan bagi ibu rumah tangga (Martha, 2015).

Pertanyaan ketiga yaitu mengenai teknik pemasakan yang dapat menghilangkan kadar iodium paling banyak pada garam terjawab salah sebesar 67,6\%. Menurut WHO cara pengolahan bahan makanan berpengaruh dengan kadar iodium dalam garam. Proses menggoreng akan kehilangan sekitar 20\% iodium, memanggang kehilangan $23 \%$ dan merebus akan kehilangan iodium cukup besar yaitu 58\% sehingga semua teknik pemasakan akan menghilangkan kandungan iodium dalam garam.

Selain 3 item pertanyaan diatas yang lebih banyak dijawab salah oleh responden, terdapat 3 item pertanyaan yang paling banyak dijawab benar oleh reponden yaitu mengenai apa manfaat garam beriodium, sumber iodium selain garam dan cara memilih garam yang baik. Pertanyaan mengenai manfaat garam beriodium, sebesar $89,2 \%$ sudah mengetahui bahwa garam beriodium bermanfaat untuk mencegah penyakit gondok. Untuk sumber iodium selain garam, 92,8\% responden menjawab ikan laut dan garam yang dikemas dan bermerek (memiliki tulisan garam iodium dan kandungan 30-80 ppm) merupakan ciri dari garam yang baik.

Untuk 3 item pertanyaan yang paling banyak dijawab salah oleh masyarakat mencirikan kurangnya informasi lebih detail mengenai garam beriodium dari petugas kesehatan maupun pemerintah. Dari hasil kuesioner mengenai pernah tidaknya mendapatkan promosi kesehatan mengenai garam beriodium $37,8 \%$ responden menjawab belum pernah mendapatkan proposi kesehatan mengenai garam beriodium oleh petugas kesehatan. Berdasarkan hasil wawancara dengan salah satu kader, promosi kesehatan mengenai garam beriodium pernah dilakukan dalam rangka mengurangi prevalensi stunting, promosi kesehatan hanya berupa himbauan untuk menggunakan garam beriodium dirumah tangga dan belum mencakup informasi detail mengenai garam beriodium seperti cara penggunaan dan penyimpanan yang benar.

Pemantauan mengenai kandungan iodium dalam garam yang beredar di masyarakat juga penting untuk dilakukan, sesuai dengan pedoman pelaksanaan pemantauan garam beriodium dimana pemantauan garam beriodium di tingkat 
masyarakat dilakukan 2 kali dalam satu tahun. Pemantauan ini dilaksanakan di Sekolah Dasar/ MI yang dilaksanakan oleh petugas gizi Puskesmas dan guru yang ditunjuk oleh kepala sekolah. Berdasarkan hasil penelitian diketahui sebesar $72,1 \%$ responden belum pernah dilakukan pengecekan garam beriodium di wilayah kerja Puskesmas Tampaksiring I.

Sebesar 40,5\% responden masih memiliki pengetahuan kurang. Kurangnya pengetahuan ibu mengenai garam beriodium juga disebabkan oleh beberapa faktor seperti rendahnya pendidikan ibu. Menurut Rahayu (2014) pendidikan dibagi menjadi 2 kategori yaitu pendidikan rendah apabila tingkat pendidikan SMP kebawah dan pendidikan tingga apabila tingkat pendidikan SMA keatas (Rahayu and Khairiyati, 2014). Dari hasil yang didapat sebesar $71,2 \%$ responden memiliki pendidikan rendah, 23,4\% diantaranya tidak bersekolah dan $28,8 \%$ responden memiliki pendidikan tinggi. Disamping itu tidak ada rasa ingin tahu ibu untuk mencari informasi mengenai garam beriodium juga berperan penting dalam rendahnya pengetahuan ibu mengenai garam beriodium.

\section{SIMPULAN}

Berdasarkan hasil penelitian dan pembahasan diatas, dapat disimpulkan bahwa sebagian besar responden memiliki pendidikan rendah dan sehari-hari sebagai ibu rumah tangga. Pengetahuan ibu rumah tangga mengani garam beriodium tergolong baik. Pengetahuan ibu rumah tangga yang tergolong baik dalam mengetahui manfaat garam beriodium, sumber iodium selain garam dan cara memilih garam yang baik. Namun, ibu rumah tangga belum memahami cara penggunaan garam beriodium yang benar, perubahan warna garam pada saat ditetesi iodine test dan teknik pemasakan yang menghilangkan kadar iodium paling banyak. Promosi kesehatan mengenai garam beriodium sudah pernah dilakukan namun hanya himbauan untuk menggunakan garam beriodium untuk menurunkan angka stunting. Promosi kesehatan yang diberikan belum mencakup informasi seperti cara penggunaan garam beriodium yang benar.

\section{SARAN}

Disarankan agar meningkatkan promosi kesehatan mengenai garam beriodium kepada masyarakat. Tidak hanya anjuran untuk menggunakan garam beriodium namun juga informasi detail lainnya seperti cara penggunaan garam yang baik.

\section{UCAPAN TERIMAKASIH}

Ucapan terimakasih disampaikan kepada Puskesmas Tampaksiring I, Kader posyandu dan Ibu rumah tangga di wilayah kerja Puskesmas Tampaksiring I, Dosen dan staff PSSKM FK Unud, keluarga dan teman-teman yang telah membantu dalam menyelesaikan artikel ini.

\section{DAFTAR PUSTAKA}

Darmono, S. S. (2009) 'Penghentian Kapsul Minyak Iodium untuk Program GAKI', Jurnal GAKI Indonesia, 1(1\&2), pp. 27-31.

Devi, M. (2012) 'Hubungan Penggunaan 
Garam Beriodium dengan Pertumbuhan Linier Anak', TIBBS (Teknologi Industri Boga dan Busana), 3(1), pp. 52-57.

Dinas Kesehatan Kabupaten Gianyar, (2019) Laporan Gizi 2019.

Hikmat, A. (2014) 'Kreativitas, Kemampuan Membaca, dan Kemampuan Apresiasi Cerpen', Jakarta. Uhamka.

Imelda, Rahman, N. and Nur, R. (2018) 'Faktor risiko kejadian stunting pada anak umur 2-5 tahun di Puskesmas Biromaru Risk factors on stunting among children age 25 years old in Biromaru of center public health', Jurnal Gizi dan Kesehatan, 2(1), pp. 39-43. Available at: http://jurnal.untad.ac.id/jurnal/ind ex.php/ghidza.

Kemenkes RI (2017) Hasil Pemantauan Status Gizi ( PSG ) Tahun 2017.

Kemenkes RI (2020) 'Rencana Aksi

Kegiatan Direktorat Gizi

Kesehatan Masyarakat Tahun 2020-2025', pp. 1-51.

Kemenkes RI (2021) 'Evaluasi Capaian Kinerja Program Gizi Tahun 2020 Indikator Program Gizi Tahun 2020 - 2024'.

Martha, V. S. (2015) Gambaran Perilaku Ibu Rumah Tangga Dalam Penggunaan Garam Beriodium Di Desa Bangun I Kecamatan Parbuluan Kabupaten Dairi Tahun 2014. Universitas Sumatera Utara.
Merryana Adriani, S. K. M. (2012) Pengantar gizi masyarakat. Prenada Media.

Notoatmodjo, S. (2003) 'Pendidikan dan perilaku kesehatan', Jakarta: rineka cipta, 16, pp. 15-49.

Notoatmodjo, S. (2010) 'Ilmu kesehatan masyarakat'. Bumi Aksara.

Rahayu, A. and Khairiyati, L. (2014) 'Risiko pendidikan ibu terhadap kejadian stunting pada anak 6-23 bulan', Nutrition and Food Research. National Institute of Health Research and Development, Indonesian Ministry ..., 37(2), pp. 129-136.

Siltrakool, B. (2018) 'Assessment of community pharmacists' knowledge, attitude and practice regarding non-prescription antimicrobial use and resistance in Thailand'.

Wirakusuma, I. B. (2016) 'Gambaran Pengetahuan Sikap dan Perilaku Ibu Rumah Tangga Terhadap Penggunaan Garam Beriodium di Wilayah Kerja Puskesmas Petang II, Kabupaten Badung'.

World Health Organization (2007) 'Assessment of the Iodine Deficiency Disorders and monitoring their elimination', pp. 1-107. Available at: https://apps.who.int/iris/bitstream/ handle/10665/43781/9789241595827 _eng.pdf. 